\title{
ANALISIS STRATEGI PENGEMBANGAN BISNIS PPOB KIPO MENGGUNAKAN ANALISIS SWOT DAN QSPM
}

\author{
TEGUH BAROTO* DAN CHANDRA PURBOHADININGRAT \\ Jurusan Teknik Industri, Fakultas Teknik, Universitas Muhammadiyah Malang \\ Jl. Raya Tlogomas 246, Malang, Jawa Timur 65144 \\ Surel: teguhbaroto@gmail.com
}

\begin{abstract}
ABSTRAK
Melihat persaingan semakin ketat di antara perusahaan penyedia jasa pembayaran online (seperti listrik, air, dan telepon), hal ini yang membuat pentingnya strategi untuk meningkatkan daya saing PT X Malang. Cara terbaik dalam meningkatkan persaingan adalah dengan melibatkan langsung faktor-faktor internal dan eksternal yang berkaitan dengan kekuatan, kelemahan, peluang dan ancaman. Analisis SWOT dan QSPM digunakan dalam penelitian ini untuk merumuskan dan memilih strategi yang tepat untuk daya saing perusahaan. Dari hasil analisis matriks SWOT dirumuskan empat strategi SO, lima strategi WO, tiga strategi ST, dan dua strategi WT. Dalam diagram kartesius posisi perusahaan berada pada strategi WO. Berdasarkan hasil perhitungan matriks QSPM, prioritas pemilihan strategi WO secara berturut-turut adalah penambahan feature-feature produk pelayanan jasa dengan bobot 4,75; memanfaatkan fasilitas internet dalam kegiatan promosi dan pemasaran dengan bobot 3,88; memanfaatkan jaringan instansi pemerintahan dan perusahaan lain secara maksimal dengan bobot 3,84; meningkatkan fasilitas pelayanan loket-loket kios pembayaran online dengan bobot 3,77; dan membuat rencana kerja yang sistematis dengan bobot 3,58.
\end{abstract}

Kata kunci: strategi bisnis, analisis SWOT, matriks QSPM

\begin{abstract}
Paying attention to the tight competition between the company competitors, online transaction service provider (i.e. electricity, water, and telephone), this is the thing which trigers to do concern about the importance of strategy for improving competition ability of PT X. The distinguished way for improving competition ability is by directly involving internal and external factors which are related to strenght, weakness, opportunity, and threat. SWOT (Strenght-Weakness-Opportunity-Threat) analysis and QSPM (Quantitative Strategic Planning Matrix) are used in this researh to determine and select the most appropriate strategy in order to improve ability in competition. From the result of SWOT analysis, it is determined four strategies of $\mathrm{S}-\mathrm{O}$ (Strenght-Opportunity), five strategies of $\mathrm{W}-\mathrm{O}$ (Weakness-Opportunity), three strategies of S-T (Strength-Threat), and two strategies of W-T (Weakness-Threat). On the cartesius diagram, position of company's competition ability is drop in W-O strategies. In accordance with QSPM matrix, the priority in selecting W-O strategies is ranked from the highest to smallest weight. The priority is respectively providing additional features of service product with weight 4.75; utilizing internet facility for promotion and marketing with weight 3,88; utilizing properly government and other companies' network with weight 3.84; improving facility of payment point of online transaction with weight 3.77; and making a sistematic work plan with weight 3.58 .
\end{abstract}

Key words: business strategy, SWOT analysis, QSPM matrix

\section{PENDAHULUAN}

Dalam era perdagangan bebas, setiap perusahaan menghadapi persaingan yang ketat. Meningkatnya intensitas persaingan dari pesaing menuntut perusahaan untuk selalu memperhatikan kebutuhan dan keinginan

* Penulis korespondensi 
konsumen serta berusaha memenuhi harapan konsumen dengan cara memberikan pelayanan yang lebih memuaskan daripada yang dilakukan oleh pesaing. Dengan demikian, hanya perusahaan yang berkualitas yang dapat bersaing dan menguasai pasar. Tan dan Ahmad (1999) menyatakan bahwa strategi perusahaan merupakan rumusan perencanaan komprehensif tentang bagaimana perusahaaan akan mencapai misi dan tujuannya. Strategi akan memaksimalkan keunggulan kompetitif dan meminimalkan keterbatasan bersaing.

Sebagai organisasi usaha profesional yang menangani pelayanan transaksi pembayaran listrik, telepon, PDAM, dan lain-lain yang tersebar di seluruh Jawa, Bali, dan Nusa Tenggara, PT "X" dengan KIPO (Kios Pembayaran Online) Cabang Malang senantiasa berusaha untuk maju, sehingga perusahaan mampu bersaing dalam era pasar bebas, dan dapat memenuhi kebutuhan konsumen dalam melakukan bisnis Payment Point Online Bank (PPOB) maupun penggunaan jasa tersebut. Untuk mewujudkan semua itu, perusahaan tentunya harus mempunyai strategi dalam menghadapi persaingan bisnis pembayaran online. Selama ini perusahaan masih memiliki kelemahan di faktor internal dan eksternal dalam menghadapi persaingan bisnis dengan perusahaan lain seperti contohnya Translink yang saat ini mempunyai kekuatan internal seperti produk yang ditawarkan lebih banyak (finance, tiket pesawat, pulsa all operator), sehingga perusahaan perlu melakukan evaluasi dan identifikasi faktor internal dan eksternal secara detail agar perusahaan memahami kekuatan dan kelemahan internal perusahaan serta mengetahui peluang serta ancaman dari perusahaan pesaing.

Berdasarkan uraian di atas, maka penelitian ini memberikan gambaran pada perusahaan untuk melakukan strategi bisnis yang maksimal dalam menghadapi persaingan. Matriks faktor internal dan eksternal, Matriks SWOT, dan QSPM (Matriks Perencanaan Strategi Kuantitatif) adalah tiga tahapan metode alternatif yang bisa menjawab atas permasalahan tersebut. Pemilihan strategi yang baik oleh perusahaan adalah tidak hanya dituntut mampu untuk membaca penilaian terhadap faktor-faktor internal perusahaan. Penilaian terhadap faktor-faktor eksternal perusahaan tidak kalah penting juga dalam menghadapi perubahan lingkungan yang terus berubah setiap saat baik sebagai peluang maupun ancaman (Gao dan Peng, 2011).

\section{METODE}

Perumusan strategi peningkatan daya saing dilakukan dengan menggunakan analisis SWOT. Sedangkan pemilihan strategi akhir ditentukan berdasarkan prioritas dari hasil QSPM. Metodologi penyelesaian permasalahan dalam penelitian ini dapat dilihat pada Gambar 1.

Tahap pertama yang dilakukan adalah mengidentifikasi dan menganalisis faktorfaktor internal perusahaan yaitu kekuatan dan kelemahan dan faktor eksternal perusahaan yaitu peluang dan ancaman apa saja yang akan dihadapi, dengan membuat kuesioner dan menyebarkannya kepada pimpinan perusahaan. Evaluasi faktor eksternal adalah mengembangkan sebuah daftar dari peluang yang dapat menguntungkan sebuah perusahaan dan ancaman yang harus dihindarinya. Menurut Dyson (2000), matriks External Factor Evaluation (EFE) digunakan bagi para penyusun strategi untuk meringkas dan mengevaluasi informasi ekonomi, sosial, budaya, demografi, lingkungan, politik, pemerintahan, hukum, teknologi, dan kompetitif. Evaluasi faktor eksternal tidak bertujuan mengembangkan sebuah daftar lengkap dan menyeluruh dari setiap faktor yang dapat memengaruhi bisnis, melainkan bertujuan mengidentifikasi variabel-variabel penting yang menawarkan sebuah respons tindakan. Perusahaan harus mampu merespons secara ofensif maupun defensif terhadap berbagai faktor tersebut dengan merumuskan strategi yang bisa mengambil keuntungan dari peluang eksternal atau meminimalkan dampak dari ancaman potensial. Semua organisasi memiliki kekuatan dan kelemahan dalam area fungsional bisnis (Houben et al., 1999). Kekuatan atau kelemahan 
internal, ditambah dengan peluang atau ancaman eksternal dan pernyataan misi yang jelas, memberi landasan untuk menetapkan tujuan strategi. Menurut David et al. (2009), perusahaan dapat mengenal lebih jauh beberapa kekuatan dan kelemahan dalam dirinya dengan melakukan evaluasi faktor internal. Dalam lingkungan yang bersaing secara global, sumber keunggulan bersaing tradisional, seperti biaya tenaga kerja, biaya modal, dan bahan baku tidak lagi menjadi efektif. Rego dan Nunes (2010) menuliskan alasan pentingnya evaluasi faktor internal adalah upaya untuk mengidentifikasi kekuatan dan kelemahan perusahaan. Kekuatan, merupakan suatu kondisi perusahaan yang mampu melaksanakan semua tugasnya secara baik karena memiliki sumber daya, keterampilan, atau keunggulan-keunggulan lain relatif terhadap pesaing dan kebutuhan pasar yang dilayani atau yang ingin dilayani oleh perusahaan atau dengan kata lain kekuatan adalah kompetensi khusus.

Langkah kedua, menghitung bobot, rating, dan skor pada matriks Internal Factor Evaluation (IFE) dan External Factor Evalution (EFE). Pemberian nilai bobot berkisar dari 0 (tidak penting) sampai 1 (sangat penting) sehingga perlu disusun skala yang menunjukkan tingkat kepentingan setiap faktor. Pada penelitian ini menggunakan penilaian skala likert. Selanjutnya, rating diberikan pada setiap faktor eksternal dan internal sesuai dengan apa yang dilakukan perusahaan dalam merespons faktor tersebut. Pemberian rating dimulai dari 1-4, di mana $4=$ respons bagus, $3=$ respons di atas rata-rata, $2=$ respons rata-rata, $1=$ respons di bawah ratarata. Skor bobot atau nilai didapatkan dengan mengalikan bobot setiap faktor dengan rating. Jumlah skor bobot menunjukkan kemampuan perusahaan dalam merespons setiap faktor, baik eksternal maupun internal. Jika skor bobot lebih dari 2,5 maka perusahaan tersebut bisa dikatakan mampu secara efektif mengendalikan faktorfaktor yang berpengaruh. Bobot setiap faktor diperoleh dengan membagi skor kepentingan terhadap jumlah nilai keseluruhan skor kepentingan dirumuskan sebagai berikut:

$$
\mathrm{B}_{\mathrm{i}}=\frac{S_{i}}{\sum_{i=1}^{n} S_{i}}
$$

Di mana:

$\mathrm{B}_{\mathrm{i}}=$ Bobot faktor ke- $i \quad i=1,2,3, \ldots . \mathrm{n}$

$\mathrm{S}_{\mathrm{i}}=$ Skor kepentingan faktor ke- $i$

Langkah ketiga, membuat matriks SWOT dengan membedakan faktor-faktor kekuatan, kelemahan, peluang dan ancaman dari hasil matriks SWOT akan didapatkan empat strategi yang mungkin diterapkan oleh perusahaan. Matriks SWOT digunakan sebagai alat pencocokan yang penting untuk membantu pengambil keputusan dalam mengembangkan empat alternatif strategi: yaitu strategi S-O (kekuatan-peluang), strategi W-O (kelemahanpeluang), strategi S-T (kekuatan-ancaman), strategi W-T (kelemahan-ancaman).

Hasil analisis SWOT akan digunakan dalam pemilihan strategi yang tepat dengan menggunakan QSPM. Matriks QSPM merupakan alat analisis yang digunakan dalam tahap keputusan. QSPM menggunakan masukan dari matriks IFE dan EFE pada tahap input, serta matriks IE dan SWOT pada tahap pencocokan untuk memutuskan strategi mana yang terbaik. Strategi yang dihasilkan diharapkan dapat menjadi pertimbangan bagi pihak manajemen perusahaan dalam penetapan kebijakan strategi untuk pengembangan usaha.

QSPM digunakan untuk menentukan strategi mana yang akan dijadikan prioritas dalam pemilihan alternatif strategi yang telah direkomendasikan melalui matriks SWOT. Menurut David (2003) ada enam langkah yang diperlukan untuk mengembangkan QSPM:

1) Membuat daftar berbagai peluang/ancaman eksternal dan kekuatan/kelemahan internal utama di kolom kiri QSPM.

2) Memberikan bobot pada setiap faktor eksternal dan internal utama tersebut.

3) Mencermati matriks-matriks tahap 2 (pencocokan), dan mengidentifikasi berbagai strategi alternatif yang harus dipertimbangkan untuk diterapkan oleh organisasi. 


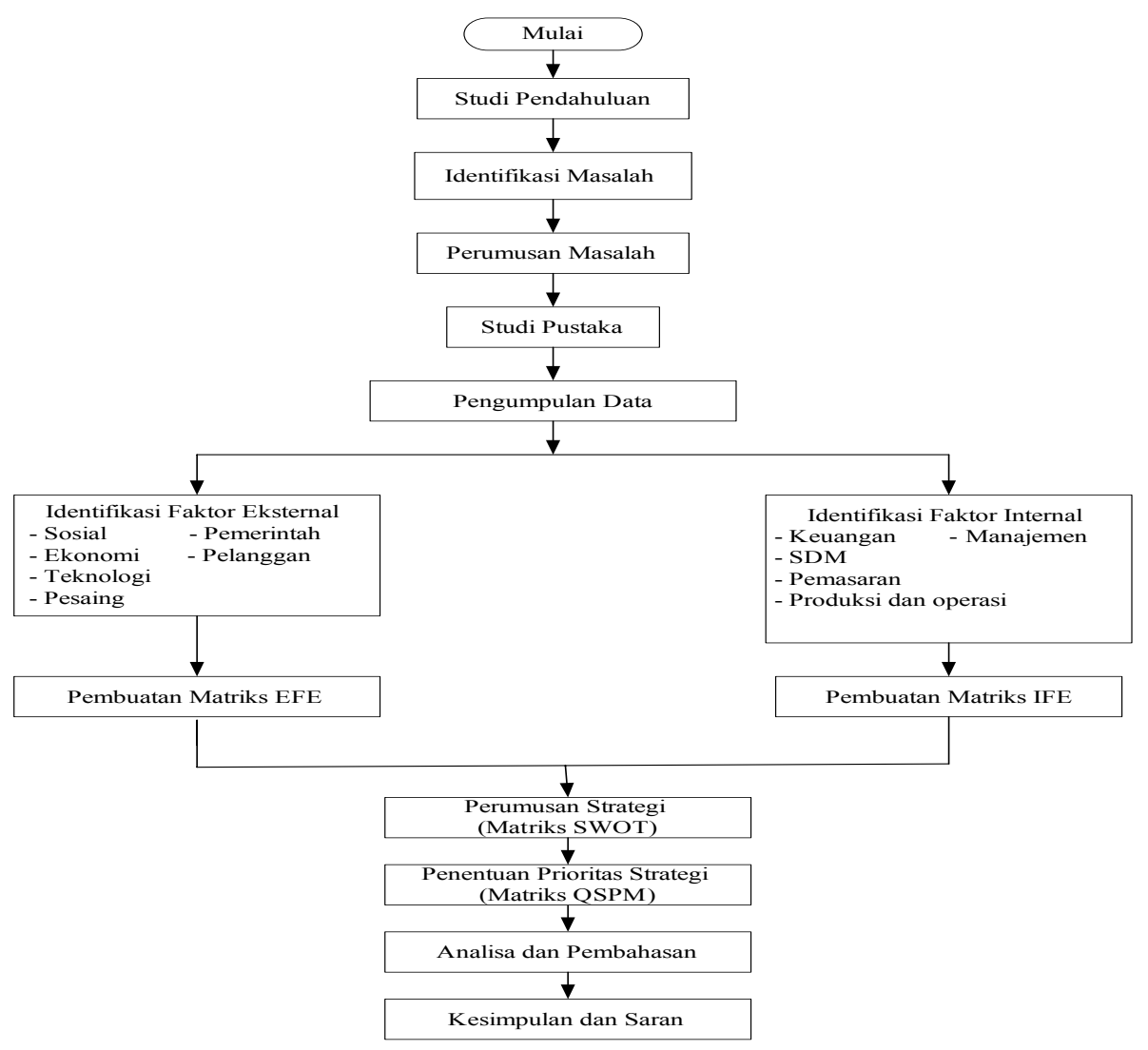

Gambar 1. Langkah Penentuan Strategi Bersaing dengan Menggunakan SWOT dan QSPM

Tabel 1. Faktor Eksternal Berupa Peluang bagi Perusahaan

\begin{tabular}{cl}
\hline Peluang & \multicolumn{1}{c}{ Keterangan } \\
\hline 1 & $\begin{array}{l}\text { Proyek Pemerintah (KEMKOMINFO) yaitu berupa Mobil Pelayanan Internet Keliling } \\
\text { (MPLIK) }\end{array}$ \\
2 & Ketertarikan perusahaan penyedia produk /jasa yang ingin bekerja sama. \\
3 & $\begin{array}{l}\text { Perkembangan teknologi proses dan informasi yang memudahkan untuk pembayaran via } \\
\text { online }\end{array}$ \\
5 & Banyak masyarakat ekonomi menengah sebagai target konsumen \\
6 & Tingginya kepercayaan loket terhadap perusahaan \\
\hline
\end{tabular}

4) Menentukan nilai daya tarik (Attractiveness Score-AS). Kisaran nilai daya tarik adalah 1 = tidak memilki daya tarik, 2 = daya tarik rendah, $3=$ daya tarik sedang, $4=$ daya tarik tinggi.

5) Menghitung nilai daya tarik total, nilai daya tarik total (Total Attractiveness Score-TAS).

6) Menghitung jumlah keseluruhan daya tarik total.

\section{HASIL DAN PEMBAHASAN}

\section{Identifikasi Faktor Eksternal dan} Internal

Pelaksanaan analisis faktor eksternal sangat dibutuhkan oleh industri maupun perusahaan yang ingin mengembangkan strategi organisasi. Pada dasarnya analisis faktor eksternal bertujuan untuk mengembangkan sebuah daftar 
Tabel 2. Identifikasi Faktor Eksternal Berupa Ancaman bagi Perusahaan

\begin{tabular}{cl}
\hline Ancaman & \multicolumn{1}{c}{ Keterangan } \\
\hline 1 & Perubahan kebijakan mengenai pelayanan publik \\
2 & Pesaing mempunyai fasilitas pelayanan yang lebih (tiket online, pulsa, asuransi) \\
3 & $\begin{array}{l}\text { Bargaining power (kekuatan tawar) pelaku usaha dengan konsumen lemah disebabkan } \\
\text { konsumen dapat dengan mudah pindah ke produsen lain }\end{array}$ \\
4 & $\begin{array}{l}\text { Peningkatan jumlah bisnis sejenis di Malang yang seringkali lebih kompetitif dalam } \\
\text { persaingan }\end{array}$ \\
5 & Non aktifnya loket tanpa konfirmasi perusahaan \\
\hline
\end{tabular}

terbatas dari peluang yang dapat memberikan keuntungan perusahaan dan ancaman yang harus dihindari. Faktor-faktor eksternal yang terangkum pada Tabel 1 dan 2 meliputi kebijakan pemerintah, faktor ekonomi, faktor sosial, dan faktor teknologi.

Pelaksanaan analisis faktor eksternal sangat dibutuhkan oleh industri maupun perusahaan yang ingin mengembangkan strategi organisasinya. Pada dasarnya analisis faktor eksternal bertujuan untuk mengembangkan sebuah daftar terbatas dari peluang yang dapat memberikan keuntungan perusahaan dan ancaman yang harus dihindari.

\section{Faktor Kebijakan Pemerintah}

Tujuan lain dari pelaksanaan sistem PPOB ini yaitu terciptanya peluang bisnis jasa pelayanan pembayaran online dengan menjadi downline bank, tercipta efisiensi berskala nasional karena tercipta sinergi antara penyedia jasa layanan, instansi terkait dan perbankan, serta akan tercipta transparansi sebagai cermin dari Good Corporate Governance. Walaupun kebijakan untuk menerapkan sistem PPOB bertujuan untuk memberikan pelayanan yang lebih baik, cepat, baru, murah, dan sederhana, namun pelaksanaan kebijakan ini masih menimbulkan pertentangan dari berbagai kalangan masyarakat.

Para pihak yang menentang kebijakan PPOB ini berpendapat bahwa pungutan biaya administrasi bank akibat perjanjian yang dilakukan antara pelaku usaha dan beberapa bank dalam transaksi pembayaran, melalui sistem PPOB ini dianggap tidak transparan. Mestinya sesuai hak konsumen, terbitnya kebijakan baru itu harus diinformasikan secara benar, jelas, dan jujur. Namun demikian, informasi tersebut tidak dengan otomatis mengikat secara hukum, karena hanya perjanjian dan Undang-Undang yang menjadi sumber perikatan, sehingga banyak dari kalangan masyarakat yang menganggap bahwa kebijakan sistem PPOB ini melanggar Undang-Undang Nomor 8 Tahun 1999 tentang Perlindungan Konsumen.

\section{Faktor Ekonomi}

Pertumbuhan ekonomi yang positif sejak tahun 2000 menumbuhkan masyarakat kelas menengah di Indonesia. Konsumsi mereka menyumbang $70 \%$ dari pertumbuhan ekonomi Indonesia. Bank Dunia menyebutkan, 56,5\% dari 237 juta populasi Indonesia masuk kategori kelas menengah. Kategori kelas menengah versi Bank Dunia adalah mereka yang membelanjakan uangnya 2 dollar AS (sekitar Rp 18.000) sampai 20 dollar AS (sekitar Rp 180.000) per hari. Disebutkan, terjadi peningkatan jumlah warga kelas menengah Indonesia sebanyak 45 juta orang dari posisi tahun 2003. Sementara dari 134 juta warga kelas menengah versi Bank Dunia itu, sekitar 14 juta orang masuk rata-rata pengeluaran 6 dollar AS (Rp 54.000) sampai 20 dollar AS per hari. Sementara itu, survei Nielsen secara online mencatat ada sekitar 29 juta warga kelas menengah premium di Indonesia. Masyarakat kelas menengah ini punya gaya tersendiri dalam membeli suatu produk.

Sebagian masyarakat dari "kelas menengah baru", menginvestasikan aset mereka ke dalam 
Bisnis PPOB. Bisnis PPOB sangat menarik perhatian kalangan kelas menengah baru dikarenakan beberapa faktor, yaitu:

- Investasi awal yang sangat "murah".

- Metode bisnis yang mudah dijalankan, dikarenakan mereka melek teknologi seperti komputer dan Internet.

- Perijinan dan cara mendapatkan (akses) bisnis PPOB sangat mudah.

- Kepastian pasar (pelanggan PPOB) yang ada setiap bulan.

- Keuntungan tipis tapi pasti setiap bulan.

- Bisnis PPOB bisa dijalankan berbarengan dengan bisnis lainnya, seperti bisnis titipan kilat, bisnis tiket \& reservasi hotel, voucer HP, warung, dan lain-lain.

- Teknologi yang digunakan beragam, sehingga pilihan cara menjalankan usaha PPOB bisa disesuaikan dengan kondisi orang yang menjalankan (permodalan, pengetahuan teknologi, dll.), kondisi geografis pelanggan, kondisi pemikiran pelanggan, dan kondisi lainnya.

\section{Faktor Sosial}

Faktor sosial merupakan sekelompok orang yang sama-sama mempertimbangkan secara dekat persamaan di dalam status atau penghargaan komunitas yang secara terusmenerus bersosialisasi di antara mereka sendiri, baik secara formal dan informal. Tingkah laku konsumen juga dipengaruhi oleh faktor-faktor sosial seperti kelompok referensi, keluarga, serta peran dan status sosial konsumen. Kelompok referensi memiliki pengaruh langsung (tatap muka) atau pengaruh tidak langsung pada sikap dan perilaku seseorang. Kelas sosial kadangkadang berupa suatu sistem kasta di mana anggota dari kasta yang berbeda untuk perananperanan tertentu dapat mengubah keanggotaan kasta mereka, termasuk dalam pembelian suatu produk. Faktor sosial dapat dilihat dari hubungan dengan teman, keluarga, dan orang tua dalam memengaruhi keputusan pembelian. Semakin tinggi hubungan dengan teman, keluarga, dan orang tua, maka semakin tinggi keputusan konsumen untuk melakukan pembelian.

\section{Faktor Teknologi}

Perkembangan teknologi saat ini telah mengubah segala aktivitas manusia di segala bidang menjadi mudah dan cepat. Dengan teknologi, manusia dimudahkan untuk menyimpan data, mencari informasi paling aktual ataupun mempromosikan barang-barang yang akan dijual. Segala bentuk kemudahan ini tentu saja harus diimbangi dengan penguasaan teknologi dan kemampuan adaptasi secara kreatif sehingga memberikan dampak positif terhadap perusahaan, baik itu berupa perencanaan produksi maupun perencanaan pemasaran. Fasilitas internet, misalnya, bertindak sebagai mesin ekonomi nasional dan global yang memacu pertumbuhan. Pemanfaatan internet sebagai sarana pemasaran dapat memberikan peluang bagi pelaku usaha untuk melakukan promosi. Selain itu, internet mengubah hakikat terdalam dari peluang dan ancaman dengan meningkatkan kecepatan distribusi, menghapuskan batasanbatasan geografis tradisional, dan menegaskan kembali hubungan antara industri dengan berbagai pemasok, kreditor, konsumen dan pesaing (David et al., 2009). Tetapi yang perlu digarisbawahi adalah bagaimana teknologi ini dapat digunakan secara maksimal oleh pelaku usaha sehingga memberikan peluang yang baik untuk perkembangan industri skala kecil di masa mendatang.

\section{Identifikasi Faktor Internal}

Pada dasarnya setiap perusahaan mempunyai kekuatan dan kelemahan dalam area fungsional bisnis. Oleh karena itu, perusahaan perlu melakukan analisis faktor internal untuk mengetahui kekuatan dan kelemahan. Analisis faktor internal memiliki pengertian di mana kondisi internal dalam perusahaan berpengaruh terhadap kinerja perusahaan. Faktor-faktor internal antara lain menyangkut manajemen, produksi/operasi, pemasaran, keuangan, sumber daya manusia, budaya perusahaan, serta penelitian dan pengembangan. Adapun faktor internal yang dapat memengaruhi perkembangan bisnis PPOB di Malang antara lain manajemen, 
Tabel 3. Identifikasi Faktor Internal Berupa Kekuatan bagi Perusahaan

\begin{tabular}{cl}
\hline Kekuatan & \multicolumn{1}{c}{ Keterangan } \\
\hline 1 & Tidak ada biaya regristrasi awal \\
2 & Biaya operasional loket sebagian gratis (kertas, tinta, spanduk) \\
3 & Memiliki kerja sama dengan project KEMKOMINFO (MPLIK) \\
4 & Hubungan yang baik dan kekeluargan antar KIPO dengan loket \\
5 & Memiliki sistem transaksi pembayaran yang mudah dan cepat dibandingkan pesaing \\
6 & Memiliki SDM yang cukup untuk maintenance loket \\
\hline
\end{tabular}

Tabel 4. Identifikasi Faktor Internal Berupa Kelemahan bagi Perusahaan

\begin{tabular}{cl}
\hline Kelemahan & \multicolumn{1}{c}{ Keterangan } \\
\hline 1 & Produk yang ditawarkan hanya sedikit dibandingkan dengan perusahaan pesaing. \\
2 & Keuntungan yang diberikan lebih kecil dibandingkan dengan perusahaan pesaing \\
3 & Kurang melakukan promosi untuk produk melalui media teknologi informasi \\
4 & Tergolong pendatang baru di malang dalam bisnis PPOB \\
5 & Jumlah pelunasan per bulan yang masih belum memenuhi target (10.000-13.000 \\
6 & pelunasan $)<(25.000$ pelunasan $)$ \\
\hline
\end{tabular}

produksi/operasi, keuangan, pemasaran, sumber daya manusia dan budaya industri, serta penelitian dan pengembangan. Seluruh faktor internal terangkum pada Tabel 3 dan 4 .

Adapun faktor internal yang memengaruhi perkembangan bisnis PPOB di Malang diantaranya:

\section{Manajemen}

Dalam ilmu manajemen, fungsi manajemen terdiri dari lima aktivitas utama yaitu perencanaan, pengorganisasian, pemotivasian, penempatan staf, dan pengontrolan. Dari kelima unsur tersebut dapat dikatakan pelaku usaha belum menerapkan manajemen dalam usahanya. Karena saat ini KIPO cabang Malang dalam hal manajemen masih kurang maksimal seperti membuat sistem kerja yang sistematis dan sebagian laporan keuangan masih dibuat secara manual.

\section{Produksi/Operasi}

Dalam proses produksi, KIPO cabang Malang masih belum memaksimalkan di bagian sistem pelayanan pembayaran, walaupun dalam hal sistem KIPO masih terhitung lebih baik dibandingkan dengan vendor yang lain.

\section{Keuangan}

Pengaturan keuangan KIPO cabang Malang sudah cukup baik, berupa penerapan dalam buku akuntansi dan pembuatan laporan di komputer. Oleh karena itu manajemen keuangan memberikan dampak positif bagi pelaku usaha karena alur keuangan perusahaan dapat dikontrol dengan cukup baik.

\section{Pemasaran}

Pendistribusian produk/jasa yang dihasilkan pelaku usaha perlu memiliki strategi pemasaran yang tepat. Cakupan strategi pemasaran meliputi 7 fungsi utama, yaitu analisis konsumen, penjualan produk, perencanaan produk, penetapan harga, distribusi, riset pemasaran, dan analisis peluang. Dalam hal promosi produk, pelaku usaha tidak memiliki strategi khusus untuk melakukan promosi. Mayoritas pelaku usaha mengandalkan promosi melalui mulut ke mulut yang tidak dapat dijadikan tolak ukur sebagai strategi pemasaran yang efektif. Kemudahan teknologi informasi saat ini belum dimanfaatkan secara maksimal sehingga menghambat promosi produk/jasa. Selain itu, pasar tidak dapat diprediksi dan setiap saat selalu berubah. Sementara itu mengenai distribusi produk/jasa, beberapa pelaku usaha 
telah memiliki wilayah penjualan masing-masing. Tetapi cakupan pendistribusian sebagian besar masih terbatas di Kabupaten Malang. Sedangkan pesaing semakin banyak bermunculan sehingga daya saing untuk memperebutkan pasar cukup tinggi.

\section{Sumber Daya Manusia dan Budaya Industri}

Usaha PPOB ini berpeluang cukup besar untuk produktivitas masyarakat, dalam hal ekonomi PPOB juga cukup membantu sehingga Perusahaan BUEP selain pemanfaatan peluang bisnis juga memaksimalkan sumber daya sekitar untuk bisa mandiri dalam usaha dan bisa mengurangi tingkat pengangguran.

\section{Penelitian dan Pengembangan}

Seperti mayoritas industri kecil yang lain, penelitian dan pengembangan adalah tugas utama masyarakat akademik dan pemerintah untuk dapat memberikan kontribusi terhadap perkembangan bisnis PPOB. Selama ini bisnis
PPOB belum tersentuh secara maksimal sebagai objek penelitian untuk mengembangkan sentra yang selama ini ada. Bisnis PPOB tidak dapat berkembang apabila pemerintah nihil memberikan perhatian.

\section{Pembuatan Matriks IFE dan EFE}

Berdasarkan hasil penyebaran kuesioner analisis faktor eksternal dan internal pada Tabel 1-4, maka selanjutnya adalah membuat matriks IFE dan EFI untuk mengetahui bobot dan rating masing-masing faktor-faktor eksternal dan internal utama yang hasilnya diperlihatkan pada Tabel 5 dan 6 . Bobot menyatakan tingkat kepentingan relatif suatu faktor terhadap keberhasilan KIPO Malang, terutama peluang dan ancaman yang memberikan dampak langsung terhadap perusahaan. Sedangkan rating menyatakan peringkat yang diberikan untuk mengetahui seberapa efektif strategi KIPO Malang saat ini dalam merespons peluang dan ancaman.

Tabel 5. Matriks Evaluasi Faktor Eksternal (EFE)

\begin{tabular}{|c|c|c|c|}
\hline Faktor-Faktor Eksternal Utama & Bobot & Rating & Nilai \\
\hline \multicolumn{4}{|l|}{ Peluang } \\
\hline $\begin{array}{l}\text { Proyek Pemerintah (KEMKOMINFO) yaitu berupa Mobil } \\
\text { Pelayanan Internet Keliling (MPLIK) }\end{array}$ & 0,1 & 3,4 & 0,34 \\
\hline $\begin{array}{l}\text { Ketertarikan perusahaan penyedia produk /jasa yang ingin } \\
\text { bekerja sama. }\end{array}$ & 0,1 & 3,4 & 0,34 \\
\hline $\begin{array}{l}\text { Perkembangan teknologi proses dan informasi yang } \\
\text { memudahkan untuk pembayaran via online }\end{array}$ & 0,11 & 3,8 & 0,418 \\
\hline $\begin{array}{l}\text { Banyak masyarakat ekonomi menengah sebagai target } \\
\text { konsumen }\end{array}$ & 0,09 & 3,2 & 0,288 \\
\hline Tingginya kepercayaan loket KIPO terhadap perusahaan & 0,09 & 3,4 & 0,306 \\
\hline $\begin{array}{l}\text { Keinginan masyarakat yang tinggi dalam melakukan } \\
\text { usaha }\end{array}$ & 0,09 & 2,6 & 0,234 \\
\hline \multicolumn{4}{|l|}{ Ancaman } \\
\hline Perubahan kebijakan mengenai pelayanan publik & 0,11 & 3,4 & 0,374 \\
\hline $\begin{array}{l}\text { Pesaing mempunyai fasilitas pelayanan yang lebih (tiket } \\
\text { online, pulsa, finance) }\end{array}$ & 0,1 & 1,8 & 0,18 \\
\hline $\begin{array}{l}\text { Bargaining power (kekuatan tawar) pelaku usaha dengan } \\
\text { konsumen lemah disebabkan konsumen dapat dengan } \\
\text { mudah pindah ke produsen lain }\end{array}$ & 0,1 & 2,6 & 0,26 \\
\hline $\begin{array}{l}\text { Peningkatan jumlah bisnis sejenis di Malang yang } \\
\text { seringkali lebih kompetitif dalam persaingan }\end{array}$ & 0,06 & 3 & 0,18 \\
\hline Non aktifnya loket tanpa konfirmasi perusahaan & 0,05 & 2 & 0,1 \\
\hline Total & 1,00 & & 3,02 \\
\hline
\end{tabular}


Tabel 6. Matriks Evaluasi Faktor Internal (IFE)

\begin{tabular}{lccc}
\hline \multicolumn{1}{c}{ Faktor-Faktor Internal Utama } & Bobot & Rating & Nilai \\
\hline $\begin{array}{l}\text { Kekuatan } \\
\text { Tidak ada biaya registrasi awal }\end{array}$ & 0,09 & 2,8 & 0,252 \\
$\begin{array}{l}\text { Biaya operasional loket sebagian gratis (kertas, tinta, } \\
\text { spanduk) }\end{array}$ & 0,09 & 2,4 & 0,216 \\
$\begin{array}{l}\text { Memiliki kerja sama dengan project KEMKOMINFO } \\
\text { (MPLIK) }\end{array}$ & 0,08 & 2,2 & 0,176 \\
$\begin{array}{l}\text { Hubungan yang baik dan kekeluargaan antar KIPO } \\
\text { dengan loket }\end{array}$ & 0,08 & 1,6 & 0,128 \\
$\begin{array}{l}\text { Memiliki sistem transaksi pembayaran yang mudah } \\
\text { dan cepat dibandingkan pesaing }\end{array}$ & 0,07 & 3 & 0,21 \\
$\begin{array}{l}\text { Memiliki SDM yang cukup untuk maintenance loket } \\
\text { Kelemahan }\end{array}$ & 0,08 & 1,8 & 0,144 \\
$\begin{array}{l}\text { Produk yang ditawarkan hanya sedikit dibandingkan } \\
\text { dengan perusahaan lain. }\end{array}$ & 0,1 & 3,2 & 0,32 \\
$\begin{array}{l}\text { Keuntungan yang diberikan lebih kecil dibandingkan } \\
\text { dengan perusahaan lain }\end{array}$ & 0,1 & 2,4 & 0,24 \\
$\begin{array}{l}\text { Kurang melakukan promosi untuk produk melalui } \\
\text { media teknologi informasi }\end{array}$ & 0,07 & 1,8 & 0,126 \\
$\begin{array}{l}\text { Tergolong pendatang baru di Malang dalam bisnis } \\
\text { PPOB }\end{array}$ & 0,06 & 1,6 & 0,096 \\
$\begin{array}{l}\text { Jumlah pelunasan per bulan yang masih belum } \\
\text { memenuhi target (10.000-13.000 pelunasan) < }\end{array}$ & 0,11 & 3,2 & 0,352 \\
$\begin{array}{l}\text { (25.000 pelunasan) } \\
\text { relum memiliki rencana kerja yang tersusun secara }\end{array}$ & 0,07 & 1,6 & 0,112 \\
\begin{tabular}{l} 
Total \\
\hline
\end{tabular} & $\mathbf{1 , 0 0}$ & & $\mathbf{2 , 3 7}$ \\
\hline
\end{tabular}

Perhitungan bobot dan rating diperoleh dari nilai rata-rata hasil kuesioner yang dibagikan kepada kelima pimpinan perusahaan yang berada di Malang. Selanjutnya bobot dan rating dikalikan untuk mengetahui nilai peluang dan ancaman yang dihadapi KIPO Malang.

Matriks EFE merupakan faktor-faktor hasil pengumpulan informasi yang berkaitan dengan faktor eksternal perusahaan meliputi faktor kebijakan pemerintah, ekonomi, sosial, dan teknologi serta analisis persaingan industri. Hasil pengumpulan informasi ini kemudian diringkas dengan mengidentifikasi faktor-faktor eksternal berupa peluang dan ancaman yang memberikan dampak bagi bisnis PPOB KIPO Malang. Peluang adalah kesempatan yang dapat dimanfaatkan oleh perusahaan untuk merumuskan strategi yang tepat dalam persaingan. Sedangkan ancaman adalah suatu kondisi di mana perusahaan mendapatkan tantangan dari pihak pesaing maupun konsumen.

Dari pengertian tersebut maka berdasarkan matriks EFE sebagaimana dapat dilihat pada Tabel 5 menunjukkan bahwa peluang yang dihadapi oleh PPOB KIPO Malang terdiri dari 6 faktor utama. Di antara faktor-faktor utama tersebut, faktor yang memberikan pengaruh paling dominan adalah proyek pemerintah (KEMKOMINFO) yaitu berupa Mobil Pelayanan Internet Keliling (MPLIK) dengan nilai sebesar 0,34 . Hal ini mengindikasikan bahwa fleksibilitas pembayaran melalui KIPO bisa lebih maksimal karena mampu menjangkau daerah pelosok. Bisnis PPOB adalah salah satu usaha untuk meningkatkan kesejahteraan ekonomi keluarga. Diharapkan untuk misi selanjutnya adalah 
menambah jumlah loket. Sedangkan untuk ancaman yang dihadapi PPOB KIPO Malang terdiri dari 5 faktor utama di mana faktor yang paling dominan memberikan ancaman adalah perubahan kebijakan mengenai pelayanan publik dengan nilai sebesar 0,374 . Perubahan kebijakan dari pemerintah dan badan usaha milik pemerintah mengenai kerja sama dalam sistem pelayanan jasa PPOB. Hal ini bisa terjadi jika perusahaan tidak mampu memenuhi target dalam tingkat pengembangan jumlah loket dan jumlah transaksi dalam setiap bulannya.

Nilai-nilai di atas menunjukkan skor bobot yang diperoleh dari perkalian bobot dengan rating. Besarnya skor bobot mengindikasikan bahwa PPOB KIPO Malang secara efektif harus mampu menarik keuntungan dari peluang yang ada dan meminimalkan ancaman yang dihadapi. Dengan total skor bobot sebesar 3,02; di mana nilai tersebut berada di atas rata-rata nilai skor bobot 2,5 maka dapat disimpulkan bahwa PPOB KIPO Malang mampu merespons dengan baik peluang dan ancaman sebagai pertimbangan dalam perumusan strategi yang akan diputuskan.

Kemampuan internal sebuah perusahaan ditandai dengan potensi kekuatan dan kelemahan yang dimiliki. Kekuatan artinya suatu kondisi perusahaan yang mampu melaksanakan semua tugas secara baik karena memiliki sumber daya, atau keunggulan-keunggulan lain relatif terhadap pesaing dan kebutuhan masyarakat yang dilayani atau yang ingin dilayani oleh KIPO atau dengan kata lain kekuatan adalah kompetensi khusus. Sebaliknya, kelemahan merupakan kondisi di mana KIPO masih kurang mampu melaksanakan pengembangan dengan baik karena memiliki keterbatasan atau kekurangan dalam sumber daya masyarakat.

Berdasarkan matriks Internal Faktor Evaluation (IFE) pada Tabel 6, faktor kekuatan yang paling dominan adalah tidak ada biaya registrasi awal dengan nilai sebesar 0,25. Hal ini berarti bahwa perusahaan harus tetap melakukan peningkatan kemudahan konsumen untuk memiliki usaha. Karena salah satu faktor pendukung dalam mengatasi keinginan konsumen dalam usaha adalah dengan memberikan kemudahan konsumen di permasalahan biaya dengan tidak adanya biaya registrasi awal. Sedangkan faktor kelemahan yang paling dominan adalah produk pelayanan jasa yang hanya sedikit dibandingkan dengan perusahaan lain, dengan nilai bobot 0,32 . Perkembangan kemajuan teknologi dan persaingan yang ketat, menuntut perusahaan untuk melakukan pengembangan-pengembangan produk yang dimiliki perusahaan. Hal ini dimungkinkan untuk menyiapkan strategi yang digunakan dalam menghadapi persaingan, jadi tidak hanya mengandalkan sistem transaksi yang lancar tetapi juga harus mempunyai berbagai macam variansi produk untuk ditawarkan. Selanjutnya skor bobot di bawah 2,5 menunjukkan perusahaan lemah secara internal, sedangkan skor bobot berada diatas 2,5 mengindikasikan posisi internal yang kuat. Nilai total skor bobot yang dimiliki PPOB KIPO Malang adalah 2,37, sehingga berada dalam posisi lemah secara internal.

\section{Perumusan Strategi dengan Matriks SWOT}

Perumusan strategi dengan matriks SWOT dibuat berdasarkan analisis matriks EFE dan matriks IFE dengan cara mencocokkan faktorfaktor peluang dan ancaman dengan faktor-faktor kekuatan dan kelemahan. Tujuan dari pembuatan matriks SWOT adalah mengumpulkan sebanyak mungkin alternatif-alternatif strategi yang mungkin digunakan oleh pelaku usaha. Matriks ini digunakan untuk mengembangkan empat jenis strategi, yaitu strategi S-O (kekuatanpeluang), strategi W-O (kelemahan-peluang), strategi S-T (kekuatan-ancaman), dan W-T (kelemahan-ancaman).

Berdasarkan perumusan strategi sebagaimana dapat dilihat pada Tabel 7, alternatif-alternatif strategi dari matriks SWOT adalah sebagai berikut: 
Tabel 7. Matrik SWOT

\begin{tabular}{|c|c|c|}
\hline $\begin{array}{l}\text { EFAS (Eksternal Strategic } \\
\text { Factors Analysis Summary) }\end{array}$ & $\begin{array}{l}\text { Kekuatan (S) } \\
\text { 1. Tidak ada biaya registrasi awal } \\
\text { 2. } \begin{array}{l}\text { Biaya operasional loket sebagian gratis } \\
\text { (kertas, tinta, spanduk) } \\
\text { 3. Memiliki kerja sama dengan proyek } \\
\text { KEMKOMINFO (MPLIK) } \\
\text { 4. Hubungan yang baik dan kekeluargaan } \\
\text { antar KIPO dengan loket } \\
\text { 5. Memiliki sistem transaksi pembayaran } \\
\text { yang mudah dan cepat dibandingkan } \\
\text { pesaing } \\
\text { Memiliki SDM yang cukup untuk } \\
\text { maintenance loket }\end{array}\end{array}$ & $\begin{array}{l}\text { Kelemahan (W) } \\
\text { 1. Produk yang ditawarkan hanya } \\
\text { sedikit dibandingkan dengan vendor } \\
\text { lain. } \\
\text { 2. Keuntungan yang diberikan lebih } \\
\text { kecil dibandingkan dengan vendor } \\
\text { lain } \\
\text { 3. Kurang melakukan promosi untuk } \\
\text { produk melalui media teknologi } \\
\text { informasi } \\
\text { Tergolong pendatang baru di Malang } \\
\text { dalam bisnis PPOB } \\
\text { 5. Jumlah pelunasan per bulan yang } \\
\text { masih belum memenuhi target } \\
\text { (10.000-13.000 pelunasan) < (25.000 } \\
\text { pelunasan) } \\
\text { Belum memiliki rencana kerja yang } \\
\text { tersusun secara rapi dan sistematis }\end{array}$ \\
\hline $\begin{array}{l}\text { Peluang (O) } \\
\text { 1. Proyek Pemerintah (KEMKOMINFO) } \\
\text { yaitu berupa Mobil Pelayanan } \\
\text { Internet Keliling (MPLIK) } \\
\text { 2. Ketertarikan perusahaan penyedia } \\
\text { produk/jasa yang ingin bekerja } \\
\text { sama. } \\
\text { 3. Perkembangan teknologi proses dan } \\
\text { informasi yang memudahkan untuk } \\
\text { pembayaran via online } \\
\text { 4. Banyak masyarakat ekonomi } \\
\text { menengah sebagai target konsumen } \\
\text { 5. Tingginya kepercayaan loket KIPO } \\
\text { terhadap perusahaan } \\
\text { 6. Keinginan masyarakat yang tinggi } \\
\text { dalam melakukan usaha }\end{array}$ & $\begin{array}{l}\text { Strategi SO } \\
\text { 1. } \begin{array}{l}\text { Meningkatkan kualitas pelayanan } \\
\text { (S1,S2, S5,S6,O1, O3) }\end{array} \\
\text { 2. Meningkatkan jumlah loket dengan } \\
\text { fasilitas yang bagus (S1, S2, S3,O2, O4, } \\
\text { O6) } \\
\text { 3. Mampu menjangkau daerah pelosok } \\
\text { untuk menambah jumlah pelanggan } \\
\text { (S3, O1) } \\
\text { 4. Menjaga kepercayaan loket (S4, O5) }\end{array}$ & $\begin{array}{l}\text { Strategi WO } \\
\text { 1. Penambahan feature-feature } \\
\text { produk pelayanan jasa (pulsa all } \\
\text { operator, PDAM, tiket online) } \\
\text { (W1,W3,W4,W5,O2, O3) } \\
\text { 2. Memanfaatkan fasilitas internet } \\
\text { dalam kegiatan promosi dan } \\
\text { pemasaran (W3, W4, O3, O4) } \\
\text { 3. Membuat rencana kerja yang } \\
\text { sistematis (W6, O5, O6) } \\
\text { 4emanfaatkan jaringan instansi } \\
\text { pemerintah dan perusahaan lain } \\
\text { secara maksimal (W4, W5, O1, O2) } \\
\text { 5eningkatkan fasilitas pelayanan } \\
\text { loket-loket KIPO (W4,O5) }\end{array}$ \\
\hline $\begin{array}{l}\text { Ancaman (T) } \\
\text { 1. Perubahan kebijakan mengenai } \\
\text { pelayanan publik } \\
\text { 2. Pesaing mempunyai fasilitas } \\
\text { pelayanan yang lebih (tiket online, } \\
\text { pulsa, finance) } \\
\text { 3. Bargaining power (kekuatan tawar) } \\
\text { pelaku usaha dengan konsumen } \\
\text { lemah disebabkan konsumen dapat } \\
\text { dengan mudah pindah ke produsen } \\
\text { lain } \\
\text { 4. Peningkatan jumlah bisnis sejenis } \\
\text { di Malang yang seringkali lebih } \\
\text { kompetitif dalam persaingan } \\
\text { 5. Non aktifnya loket tanpa konfirmasi } \\
\text { perusahaan }\end{array}$ & $\begin{array}{l}\text { Strategi ST } \\
\text { 1. Mengembangkan strategi pemasaran } \\
\text { yang baik sesuai dengan visi misi (S1, } \\
\text { S2, S3, S4, S5, S6, T3, T4) } \\
\text { 2. Memanfaatkan, jaringan untuk } \\
\text { menambah kualitas pelayanan (S3, } \\
\text { T1) } \\
\text { 3. Meningkatkan kepercayaan konsumen } \\
\text { terhadap pelayanan KIPO (S4, S5, S6, } \\
\text { T2, T3) }\end{array}$ & $\begin{array}{l}\text { Strategi WT } \\
\text { 1. Mengamati dan menganalisa } \\
\text { perubahan yang dilakukan } \\
\text { kompetitor (W1, W2, W3, W4, W5, } \\
\text { O1, O2, O3, O4) } \\
\text { 2. Lebih memperhatikan kualitas mutu } \\
\text { dan pelayanan terhadap konsumen } \\
\text { (W1, O2, O3, O4) }\end{array}$ \\
\hline
\end{tabular}

\section{Strategi S-O (kekuatan-peluang)}

1. Meningkatkan kualitas pelayanan. Dari hal ini, diharapkan perusahaan dapat memperkuat posisi dalam menghadapi daya saing industri yang semakin tinggi.

2. Meningkatkan jumlah loket dengan fasilitas yang bagus. Tujuan dari hal ini adalah untuk menguatkan kekuatan tawar dengan pemasok, baik berupa jasa layanan yang lain, maupun lembaga keuangan.
3. Mampu menjangkau daerah pelosok dengan tetap mendayagunakan fasilitas yang tersedia dari pemerintah. Hal ini dilakukan untuk memperbesar skala usaha dengan didukung dari kerja sama dengan instansi pemerintahan dan dapat mempermudah masyarakat untuk melakukan pembayaran tagihan.

4. Menjaga kepercayaan konsumen terhadap perusahaan adalah sebuah misi perusahaan untuk mengatasi kelemahan-kelemahan 
dengan memanfaatkan peluang yang ada, misalnya selalu memberikan pelayanan yang terbaik pada loket.

\section{Strategi S-T (kekuatan-ancaman)}

1. Mengembangkan strategi pemasaran yang baik sesuai dengan visi dan misi perusahaan. Untuk mendapatkan daya saing dengan pesaing, perusahaan diharapkan dapat meningkatkan kontribusi terhadap masyarakat dengan pelayanan prima dengan tetap mempertimbangkan dari kebutuhan konsumen.

2. Memanfaatkan jaringan untuk menambah kualitas pelayanan. Hal ini penting dilakukan karena konsumen akan mudah beralih ke produsen lain apabila pelaku usaha tidak memiliki kekuatan tawar dengan konsumen.

3. Meningkatkan kepercayaan konsumen terhadap pelayanan. Hal ini perlu dilakukan karena bentuk profesional perusahaan terhadap konsumen, misalnya memiliki sistem transaksi pembayaran yang mudah dan cepat dibandingkan pesaing.

\section{Strategi W-O (kelemahan-peluang)}

1. Penambahan feature-feature produk pelayanan jasa (all operator pulsa, PDAM, tiket online). Dengan penambahan ini diharapkan perusahaan mampu meningkatkan jumlah pelunasan dan memberikan kemudahan bertransaksi bagi masyarakat.

2. Memanfaatkan fasilitas internet dalam kegiatan promosi dan pemasaran. Kemajuan teknologi semaksimal mungkin harus dimanfaatkan untuk melakukan promosi produk dan kegiatan pemasaran.

3. Membuat rencana kerja yang sistematis. Rencana kerja yang dimaksud adalah sebuah perencanaan perusahaan meliputi pembuatan visi dan misi, perencanaan permodalan dan investasi, perencanaan pelayanan, perencanaan pemasaran, dan evaluasi kinerja perusahaan.

4. Memanfaatkan jaringan instansi pemerintah dan perusahaan lain secara maksimal. Hal ini bisa dimanfaatkan untuk mengatasi kelemahan seperti fee yang diberikan lebih kecil dibandingkan perusahaan lain dan munculnya bargaining position dalam animo masyarakat.

5. Meningkatkan fasilitas loket-loket KIPO adalah sebuah misi perusahaan untuk mengatasi kelemahan-kelemahan dengan lebih meningkatkan kepercayaan konsumen sehingga pemilik loket bisa lebih nyaman dalam bekerja.

\section{Strategi W-T (kelemahan-ancaman)}

1. Mengamati dan menganalisis perubahan yang dilakukan kompetitor. Dalam hal ini perusahaan melakukan sebuah perencanaan strategi untuk menghadapi daya saing yang tinggi dengan kompetitor.

2. Memperhatikan kualitas mutu dan pelayanan terhadap konsumen, ini adalah bentuk analisa yang diharapkan bisa menjadi referensi perusahaan untuk dapat melihat kebutuhan konsumen.

Empat strategi ini kemudian akan dipilih dengan melihat posisi bisnis PPOB ini dalam kuadran SWOT. Pertama, yang dilakukan adalah membuat kuadran dalam 4 posisi yaitu kuadran I menunjukkan posisi perusahaan berada pada strategi S-O (kekuatan-peluang), kuadran II berada pada posisi strategi W-O (kelemahan-peluang), dan kuadran III berada pada posisi strategi W-T (kelemahan-ancaman), serta kuadran IV berada pada posisi strategi S-T (kekuatan-ancaman). Kedua, adalah menentukan koordinat sumbu $\mathrm{x}$ dan sumbu y di mana sumbu $\mathrm{x}$ adalah nilai skor bobot total dari matriks IFE, sedangkan sumbu y adalah nilai skor bobot total dari matriks $\mathrm{EFE}$ dengan sumbu pusat $(\mathrm{X}=2,37$; $\mathrm{Y}=3,02$ ). Sumbu pusat tersebut diperoleh dari nilai rata-rata skor bobot total yang berkisar antara 1 sebagai titik rendah sampai 4 sebagai titik tertinggi.

Berdasarkan kuadran SWOT yang ditunjukkan pada Gambar 2, posisi PPOB KIPO Malang berada pada kuadran II dengan posisi pada sumbu x sebesar 2,37 . Sumbu x merupakan representasi dari kekuatan dan kelemahan yang dimiliki oleh PPOB KIPO Malang. Sedangkan sumbu y ditunjukkan dengan nilai 3,02 yang merupakan representasi dari peluang dan 


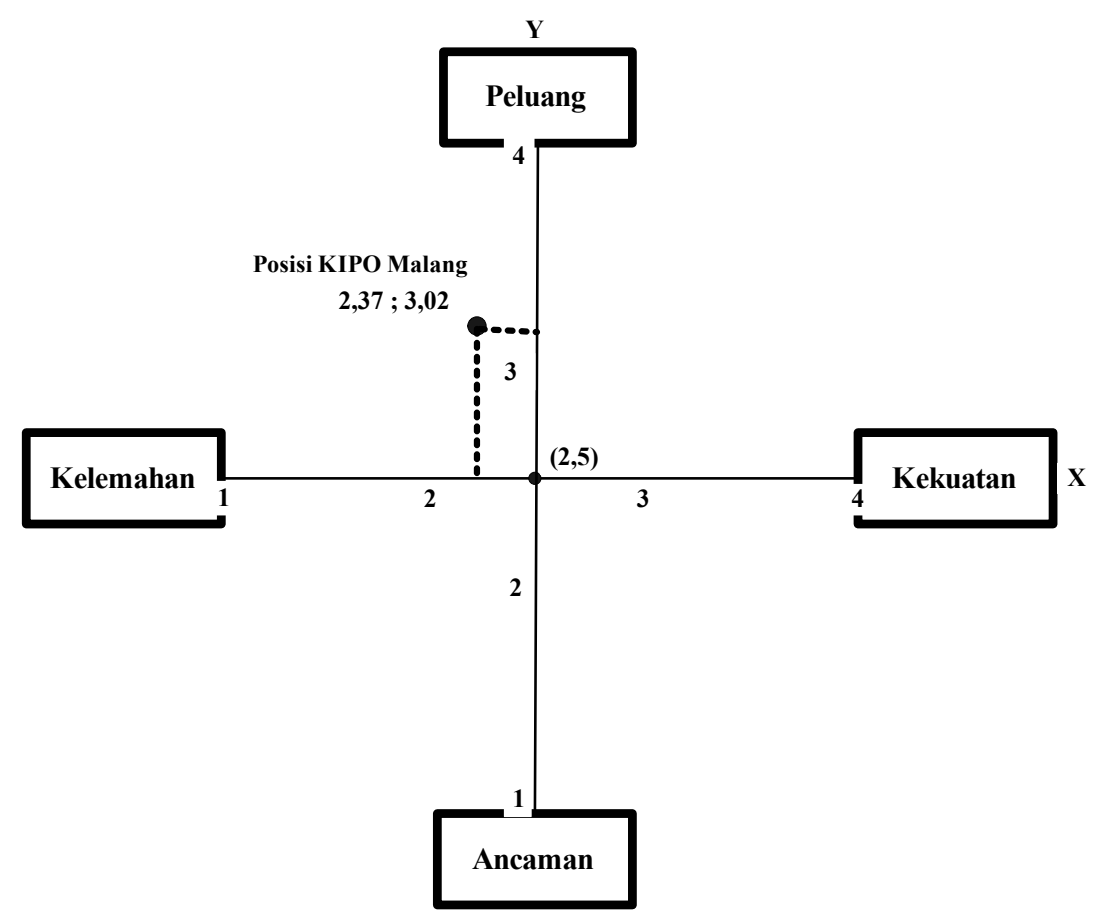

Gambar 2. Posisi KIPO Malang dalam Kuadran SWOT

ancaman yang dihadapi PPOB KIPO Malang. Maka pada posisi ini, PPOB KIPO Malang berada pada posisi strategi W-O (kelemahan-peluang) di mana perusahaan menghadapi peluang yang cukup besar sebaliknya disisi lain memiliki kendala berupa kelemahan secara internal.

\section{Penentuan Prioritas Strategi dengan Matriks QSPM}

Penyusunan matriks QSPM dibuat berdasarkan alternatif-alternatif strategi yang muncul dalam analisa SWOT dalam hal ini adalah strategi W-O (peluang-kelemahan) sebagaimana ditunjukkan oleh Gambar 2. Berdasarkan hal tersebut, maka langkah selanjutnya adalah menentukan strategi terpilih dengan cara menyebarkan kuesioner kepada kelima pimpinan perusahaan KIPO Malang sehingga dapat disusun matriks QSPM untuk memilih strategi yang akan digunakan oleh KIPO Malang.

Nilai daya tarik (AS) menunjukkan daya tarik relatif dari setiap strategi terhadap setiap faktorfaktor utama seperti ditunjukkan pada Tabel 8 . Daya tarik tinggi akan diberi nilai 4 sedangkan apabila faktor utama tidak memiliki daya tarik terhadap alternatif-alternatif strategi maka diberikan tanda nilai 1 . Selanjutnya total nilai daya tarik (TAS) diperoleh dari perkalian bobot dengan AS. Berdasarkan Tabel 8, total nilai daya tarik tertinggi yang merupakan prioritas pertama dalam pemilihan strategi adalah penambahan feature-feature produk pelayanan jasa dengan nilai TAS sebesar 4,75.

Berdasarkan hasil Matriks QSPM pada Tabel 8, mengindikasikan bahwa perusahaan perlu melakukan beberapa prioritas strategi yang diurutkan sebagai berikut: Prioritas 1 , penambahan feature-feature produk pelayanan jasa (pulsa all operator, PDAM, tiket online) dengan nilai TAS sebesar 4,75. Yang berarti bahwa strategi ini untuk menetapkan apa yang menjadi produk unggulan, produk kompetitif, produk baru, sesuai dengan kompetensi pokok yang dimiliki. Prioritas 2 , memanfaatkan fasilitas internet dalam kegiatan promosi dan pemasaran dengan nilai TAS sebesar 3,88. Strategi promosi, strategi ini merupakan kelanjutan dari pemasaran dan produksi, di mana promosi apa yang hendak diluncurkan, media apa yang akan digunakan untuk promosi dan sebagainya. 
Tabel 8. Matriks QSPM untuk Pemilihan Strategi KIPO Malang

\begin{tabular}{|c|c|c|c|c|c|c|c|c|c|c|c|}
\hline \multirow{3}{*}{$\begin{array}{c}\text { Faktor-faktor } \\
\text { Utama }\end{array}$} & \multirow{3}{*}{ Bobot } & \multicolumn{10}{|c|}{ Alternatif Strategi } \\
\hline & & \multicolumn{2}{|c|}{ Strategi 1} & \multicolumn{2}{|c|}{ Strategi 2} & \multicolumn{2}{|c|}{ Strategi 3} & \multicolumn{2}{|c|}{ Strategi 4} & \multicolumn{2}{|c|}{ Strategi 5} \\
\hline & & $\mathbf{A S}$ & TAS & $\mathbf{A S}$ & TAS & AS & TAS & $\mathbf{A S}$ & TAS & $\mathbf{A S}$ & TAS \\
\hline Peluang 1 & 0,1 & 1 & 0,1 & 1 & 0,1 & 2 & 0,2 & 4 & 0,4 & 1 & 0,1 \\
\hline Peluang 2 & 0,1 & 4 & 0,4 & 3 & 0,3 & 1 & 0,1 & 3 & 0,3 & 1 & 0,1 \\
\hline Peluang 3 & 0,11 & 2 & 0,22 & 4 & 0,44 & 1 & 0,11 & 2 & 0,22 & 1 & 0,11 \\
\hline Peluang 4 & 0,09 & 1 & 0,09 & 1 & 0,09 & 2 & 0,18 & 3 & 0,27 & 2 & 0,18 \\
\hline Peluang 5 & 0,09 & 2 & 0,18 & 1 & 0,09 & 2 & 0,18 & 1 & 0,09 & 3 & 0,27 \\
\hline Peluang 6 & 0,09 & 3 & 0,27 & 1 & 0,09 & 1 & 0,09 & 1 & 0,09 & 2 & 0,18 \\
\hline Ancaman 1 & 0,11 & 3 & 0,33 & 3 & 0,33 & 1 & 0,11 & 2 & 0,22 & 1 & 0,11 \\
\hline Ancaman 2 & 0,1 & 4 & 0,4 & 1 & 0,1 & 2 & 0,2 & 3 & 0,3 & 3 & 0,3 \\
\hline Ancaman 3 & 0,1 & 3 & 0,3 & 1 & 0,1 & 1 & 0,1 & 2 & 0,2 & 4 & 0,4 \\
\hline Ancaman 4 & 0,06 & 3 & 0,18 & 3 & 0,18 & 2 & 0,12 & 2 & 0,12 & 2 & 0,12 \\
\hline Ancaman 5 & 0,05 & 1 & 0,05 & 1 & 0,05 & 3 & 0,15 & 1 & 0,05 & 3 & 0,15 \\
\hline Kekuatan 1 & 0,09 & 2 & 0,18 & 2 & 0,18 & 1 & 0,09 & 1 & 0,09 & 1 & 0,09 \\
\hline Kekuatan 2 & 0,09 & 2 & 0,18 & 2 & 0,18 & 1 & 0,09 & 1 & 0,09 & 1 & 0,09 \\
\hline Kekuatan 3 & 0,08 & 2 & 0,16 & 1 & 0,08 & 2 & 0,16 & 4 & 0,32 & 1 & 0,08 \\
\hline Kekuatan 4 & 0,08 & 1 & 0,08 & 1 & 0,08 & 3 & 0,24 & 1 & 0,08 & 4 & 0,32 \\
\hline Kekuatan 5 & 0,07 & 2 & 0,14 & 1 & 0,07 & 1 & 0,07 & 1 & 0,07 & 1 & 0,07 \\
\hline Kekuatan 6 & 0,08 & 2 & 0,16 & 2 & 0,16 & 4 & 0,32 & 1 & 0,08 & 1 & 0,08 \\
\hline Kelemahan 1 & 0,1 & 4 & 0,4 & 3 & 0,3 & 1 & 0,1 & 1 & 0,1 & 2 & 0,2 \\
\hline Kelemahan 2 & 0,1 & 1 & 0,1 & 1 & 0,1 & 1 & 0,1 & 2 & 0,2 & 1 & 0,1 \\
\hline Kelemahan 3 & 0,07 & 2 & 0,14 & 4 & 0,28 & 2 & 0,14 & 2 & 0,14 & 1 & 0,07 \\
\hline Kelemahan 4 & 0,06 & 3 & 0,18 & 3 & 0,18 & 2 & 0,12 & 2 & 0,12 & 3 & 0,18 \\
\hline Kelemahan 5 & 0,11 & 4 & 0,44 & 3 & 0,33 & 3 & 0,33 & 2 & 0,22 & 3 & 0,33 \\
\hline Kelemahan 6 & 0,07 & 1 & 0,07 & 1 & 0,07 & 4 & 0,28 & 1 & 0,07 & 2 & 0,14 \\
\hline \multicolumn{12}{|c|}{ Jumlah Total Daya } \\
\hline Prioritas & & & I & & II & & $\mathbf{V}$ & & III & & IV \\
\hline
\end{tabular}

Prioritas 3, memanfaatkan jaringan instansi pemerintahan dan perusahaan lain secara maksimal dengan nilai TAS sebesar 3,84. Strategi ini menunjukkan strategi fungsional lainnya, ini berkaitan dengan pihak luar seperti supplier, konsultan, pemerintah dan lain sebagainya. Prioritas 4, meningkatkan fasilitas pelayanan loket-loket KIPO dengan nilai TAS sebesar 3,77. Termasuk dalam strategi sumber daya manusia (SDM), merupakan strategi yang penting dan harus mencakup seluruh fungsi manajemen. Pemilihan SDM yang tepat dan berkompeten pada bidang yang tepat sangat diperlukan guna memberikan pelayanan. Prioritas 5, membuat rencana kerja yang sistematis dengan nilai TAS sebesar 3,58.

\section{SIMPULAN}

Dengan menggunakan analisis SWOT maka menghasilkan 4 alternatif strategi yaitu S-O (meningkatkan mutu serta layanan kualitas, meningkatkan jumlah loket dengan fasilitas yang bagus, mampu menjangkau daerah pelosok, menjaga kepercayaan loket), strategi 
S-T (mengembangkan strategi pemasaran yang baik sesuai dengan visi misi, memanfaatkan jaringan untuk menambah kualitas pelayanan, meningkatkan kepercayaan konsumen terhadap pelayanan KIPO), strategi W-O (menambah feature-feature produk pelayanan jasa, memanfaatkan fasilitas internet dalam kegiatan promosi dan pemasaran, membuat rencana kerja yang sistematis, memanfaatkan jaringan instansi pemerintah dan perusahaan lain secara maksimal, meningkatkan fasilitas pelayanan loket-loket KIPO), Strategi W-T (mengamati dan menganalisis perubahan yang dilakukan kompetitor, lebih memperhatikan kualitas mutu dan pelayanan terhadap konsumen). РPOB KIPO Malang akan menggunakan strategi W-O berdasarkan posisi perusahaan dalam kuadran SWOT yang berada pada kuadran II. Prioritas strategi yang harus dijalankan oleh PPOB KIPO Malang adalah menambahkan feature-feature produk pelayanan jasa.

\section{DAFTAR PUSTAKA}

David, F.A., 2003. Manajemen Strategi, Jakarta: Pearson Education Asia Pte Ltd dan PT Prehallindo.

David, M.E., David, R.F., and David, F.R., 2009. The Quantitative Strategic Planning Matrix (QSPM) Applied to Retail Computer Store, The Coastal Business Journal, 8 (1), 42-52.

Dyson, R.G., 2000. Strategy, Performance and Operational Research, Journal of the Operational Research Society, 51, 5-11.

Gao, C-Y., and Peng, D-H., 2011. Consolidating SWOT Analysis with Non Homogeneous Uncertain Preference Information, Knowledge-Based Systems, 24 (6), 796-808.

Houben, G., Vanhoof, K., and Lenie, K., 1999. A Knowledge-Based SWOT-Analysis System as an Instrument for Strategic Planning in Small and Medium Sized Enterprises, Decision Support Systems, 26, 125-135.

Rego, G., and Nunes, R., 2010. Hospital Foundation: a SWOT Analysis, ibusiness, 2, 210-217.

Tan, T.T.W., and Ahmad, Z.U., 1999. Managing Marketing Intelligence: an Asian Marketing Research Perspective, Marketing Intelligence \& Planning, 17 (6), 298-306. 